\title{
Optical Character Recognition for Coptic fonts
}

\author{
A multi-source approach for scholarly editions \\ Eliese-Sophia Lincke \\ Institute of Archaeology \\ Humboldt-Universität zu Berlin \\ Berlin, Germany \\ eslincke@staff.hu-berlin.de \\ Kirill Bulert \\ eTRAP Research Group \\ Georg-August-Universität \\ Göttingen \\ Göttingen, Germany \\ kbulert@etrap.eu \\ Marco Büchler \\ eTRAP Research Group \\ Georg-August-Universität \\ Göttingen \\ Göttingen, Germany \\ mbuechler@etrap.eu
}

\begin{abstract}
In this paper, we show that the OCR engine Ocropy can be trained for fonts used in rather complex and varied Coptic typeset. For each of the three fonts presented in this paper, we used a number of texts from scholarly editions with different philological and editorial standards and texts from two different dialects of Coptic (Bohairic and Sahidic). Despite the complexity of the training data, we observed accuracy rates of $97.5 \%$, for one font even up to $99 \%$.
\end{abstract}

\section{CCS CONCEPTS}

- Applied computing Optical character recognition • Applied computing $\sim$ Arts and humanities

\section{KEYWORDS}

Coptic, Optical Character Recognition, digitization of cultural heritage, Ocropy/Ocropus, ScanTailor

\section{Introduction}

A significant number of Coptic texts preserved in late antique and medieval manuscripts is published in printed scholarly editions. Coptic, the (Ancient) Egyptian language in its last phase, was written in an alphabetical script based on Greek but with a single-digit number of supplemental characters originating in Demotic, ${ }^{1}$ one of the indigenous Egyptian writing systems. Coptic was spoken and written from the 2nd to 15th c. CE. There were different dialects, of which Sahidic and Bohairic are relevant for this paper. The language is now extinct but the

This work is licensed under a Creative Commons Attribution-NoDerivs International 4.0 License.

\footnotetext{
${ }^{1}$ The exact number depends on the dialect. DOI: $10.1145 / 3322905.3322931$
}

Bohairic dialect continues to be used as the liturgical language of the Coptic (Orthodox) Church.

The digitization of Coptic cultural heritage is an ongoing process. The majority of texts is not yet available in digital form. In the Coptic OCR project at the Göttingen Centre for Digital Humanities [24], the OCR engine Ocropy (also called Ocropus) [3] was used to train and test models for several fonts used in one of the major series of Coptic text editions. Our work shows that this OCR engine is capable of dealing even with very complex (by alphabetical standards) data sets.

Leaving Coptic OCR pioneer Moheb S. Mekhaiel's Tesseract approach aside [26], we build on previous work by Bulert, Miyagawa and Büchler [4], [27] and Lincke [25] but extend the corpus size and font number as well as complexity of the data sets.

\section{Data}

\subsection{Fonts}

The editions from which we selected the fonts are all part of the renowned series Corpus Scriptorum Christianorum Orientalium (CSCO), more specifically the sub-series Scriptores Coptici (CSSC). Other than the text of the New Testament and, partially, the Old Testament, which can be accessed online (e.g. [30]), only a small part of the texts of this series are published in digital form [30]. Over the years - the first volume of Scriptores Coptici was published in 1906 - at least four different fonts were used (see Fig. 1). ${ }^{2}$ In the following, we will present data from three of these fonts, which we called CSSC_1, CSSC_2 and CSSC_3 respectively. ${ }^{3}$

Due to time constraints, the editions weren't scanned but existing scans were used. These were taken from publically accessible online repositories ([6], [12], [28], [33]) where the scan resolution of the books (if disclosed at all) varied from 300 ppi to

\footnotetext{
${ }^{2}$ These fonts have also been used in Coptological publications that are not part of the CSCO series. Therefore, the models for these fonts have a larger scope of application than the one presented in this paper.

3 One further font, used in [15], was excluded because it was only used in this volume of the CSSC series.
} 
600 ppi. Obviously, this contributed to the variation of the data and was accepted as a challenge for the performance of Ocropy.

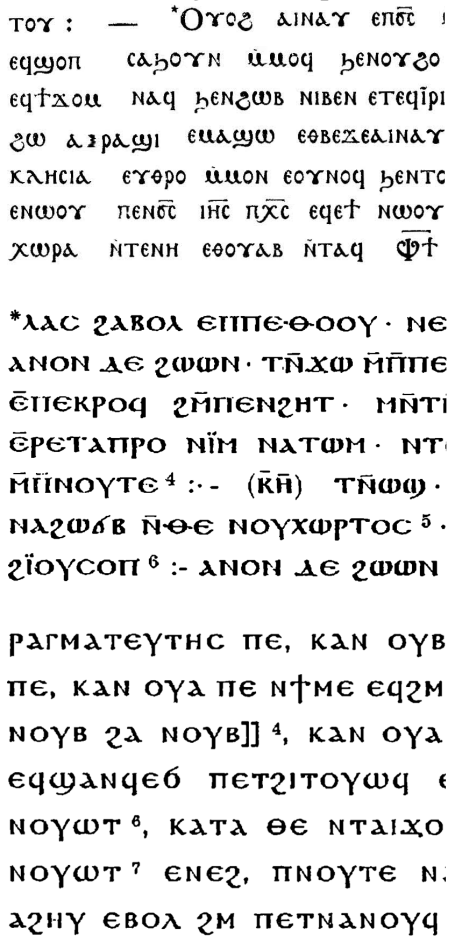

Figure 1: Three of the fonts used in the CSSC series, from top to bottom: CSSC_1 (L.Th. Lefort, CSCO), CSSC_2 (K.H. Kuhn, $\mathrm{CSCO}$ ) and CSSC_3 (T. Orlandi, CSCO $)^{4}$

\subsection{Character set}

The character sets varied from edition to edition and, where several manuscripts are published in one edition, also from text to text. The character sets are inhomogeneous in the following respects:

- dialects (the Bohairic and Sahidic dialects have slightly different character sets and the frequency of characters is different)

- inhomogeneity in the manuscripts (especially regarding punctuation and diacritics and layout, i.e. one text block versus two columns)

- characters used to mark philological modifications to the text (signalling the editor's changes or additions to the text as transmitted in an ancient manuscript)

- $\quad$ varying degrees of standardization chosen by different editors (e.g. in the punctuation, in the indication of line and page breaks in the original manuscript)

Fig. 2 shows how the set and frequency of characters varies for font CSSC_2 in two editions ([14], p. 4; [17], p. 65]. There are characters only used in the Bohairic text (b, upper part) or used

\footnotetext{
${ }^{4}$ Font samples taken from: [19], p. 202, [17], p. 26 and [29], p. 34.
}

more frequently in Bohairic than in Sahidic $(\phi)$. Diacritics (trema, supralinear strokes) are only used in Sahidic (lower part). The editor of the upper text used several different types of brackets to mark modifications to the text. Also both texts are printed with different punctuation marks.

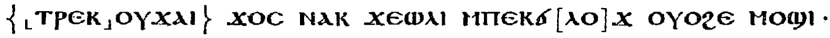

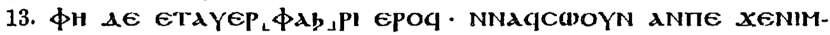

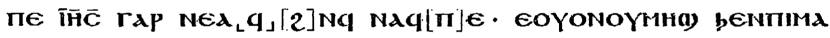

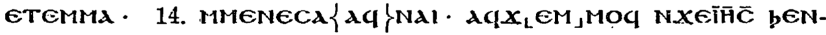

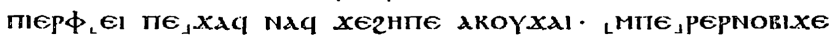

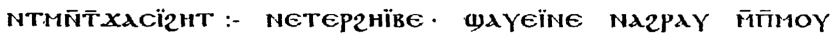

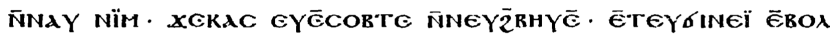

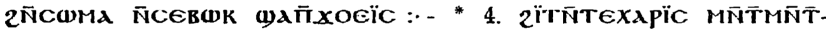

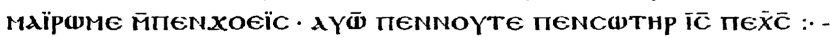

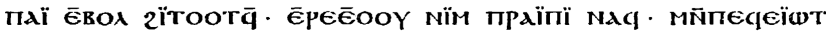

Figure 2: Variation of character sets in two texts printed in CSSC_2 (top: R. Kasser, CSCO, bottom: K.H. Kuhn, CSCO) ${ }^{5}$

While all Coptic letters and diacritics required are represented in Unicode, suitable Unicode characters could not always be identified for the punctuation signs used in the editions. Some Oriental scholars use the private use area for characters that are not part of the Unicode standard [11]. This is also the case with one of our punctuation marks ( $:$ encoded as U+10062A in [11]). We didn't follow this suggestion. Instead, we used currency symbols ( $\$, €, ¥)$ as placeholders.

\section{Methodology}

\subsection{Selection of training data}

The training process followed the recommendations of Springmann [31], although the number of training lines exceeded the recommended minimum of 300 lines due to reasons that will be explained in the following.

Training (and test) pages were selected to ensure that the complete character set was represented in the training set. Characters are very unevenly distributed in Coptic texts, with characters like $\Sigma$ and $\psi$ being rare. Also, capital letters are rare, usually only used in the opening passage of a text (but not always) or when the text layout uses ekthetic paragraph divisions (in which a single character is written to the left of the text column or line [5], p. 5). Furthermore, the Bohairic dialect has a slightly different character set compared with the Sahidic dialect, meaning that training data from both dialects needed to be collected. An overview of all training pages and pages used for the evaluation (test pages) is given in Table 1. All lines of the respective pages were used. ${ }^{6}$

In the training, fonts were kept separate, i.e. the models are font-specific. Thus, they are not mixed models in the sense of Springmann and Lüdeling [32]. However, training data has been collected in several editions using the same font. In this sense,

\footnotetext{
${ }_{6}^{5}$ Font samples taken from: [14], p. 4 and [17], p. 65.

6 Except in cases where lines were not correctly segmented by the line segmentation tool in Ocropy.
} 
the models are single-font models but can be called mixed-source models. A mixed-source model represents the diversity (number of characters in a font) and variation (characters used to represent an individual text in a font) that are attested for each font when it is used for more than one ancient text and with a number of editorial decisions as described above.

\begin{tabular}{|c|c|c|c|c|}
\hline $\begin{array}{l}\text { Fo- } \\
\text { nt }\end{array}$ & $\begin{array}{l}\text { Short reference: } \\
\text { Author-Year-Title }\end{array}$ & Training pages & $\begin{array}{l}\text { Test } \\
\text { pages }\end{array}$ & $\begin{array}{l}\text { Refer- } \\
\text { ence }\end{array}$ \\
\hline \multirow{5}{*}{$\begin{array}{l}-1 \\
\mathscr{N}^{\prime}\end{array}$} & BalHyv 1924 ActaMart & $\begin{array}{l}192,193,198,201, \\
217,239,268,274, \\
278\end{array}$ & 202,235 & {$[2]$} \\
\hline & Garitte 1949 VitAnt & $\begin{array}{l}6,9,23,29,41,66 \\
81,103,115,117 \\
123,124\end{array}$ & 1,122 & {$[10]$} \\
\hline & Lefort 1925 PachomBoh & $\begin{array}{l}149,182,202,212, \\
222,223\end{array}$ & 135 & {$[19]$} \\
\hline & Lefort 1933 PachomSah & $130,132,141,143$ & - & {$[20]$} \\
\hline & $\begin{array}{l}\text { Leipoldt Crum } 1913 \\
\text { ShenIV }\end{array}$ & $\begin{array}{l}4,17,24,71,104, \\
108,109,110,154, \\
181,183,192,193, \\
194,195,196,197\end{array}$ & 42,49 & {$[23]$} \\
\hline \multirow{6}{*}{$\begin{array}{l}v_{1}^{\prime} \\
\mathscr{W}^{\prime}\end{array}$} & Kasser 1958 BodmerIII & $4,7,49,51$ & 5 & {$[14]$} \\
\hline & Kuhn 1956 LettersBesa & $1,5,7,40$ & 119 & {$[16]$} \\
\hline & Kuhn 1960 PseudoShen & $26,47,65$ & 46 & {$[17]$} \\
\hline & Kuhn 1966 PanegJohn & 51 & 50 & {$[18]$} \\
\hline & Lefort 1955 Athan & $70,71,113$ & 69 & {$[21]$} \\
\hline & $\begin{array}{l}\text { Lefort } 1956 \text { Oeuvr } \\
\text { Pachom }\end{array}$ & 55 & 94 & {$[22]$} \\
\hline \multirow{5}{*}{$\begin{array}{l}m \\
\bigcup^{\prime} \\
\mathscr{N}^{\prime}\end{array}$} & Depuydt 1991 Hom & $29,44,47,64$ & 4 & {$[7]$} \\
\hline & Depuydt 1993 Encom & $22,42,51,98,121$ & 52 & {$[8]$} \\
\hline & $\begin{array}{l}\text { Drescher } 1970 \text { King- } \\
\text { doms }\end{array}$ & $14,16,20$ & 21 & {$[9]$} \\
\hline & $\begin{array}{l}\text { Johnson } 1980 \text { Paneg } \\
\text { Macarius }\end{array}$ & 9,15 & 14 & {$[13]$} \\
\hline & $\begin{array}{l}\text { Orlandi } 1974 \text { Const } \\
\text { Encom }\end{array}$ & 31,35 & 30 & {$[29]$} \\
\hline
\end{tabular}

Table 1: Overview of training data

Bulert, Miyagawa and Büchler [4] compared the prediction accuracy of Tesseract and Ocropy OCR models against a test corpus. The test corpus consisted of the 'original' text layout and typography, a 'clean' version in which the philological mark-up (e.g. different types of parentheses) as well as punctuation were removed and a 'simplified' version in which, additionally, the Coptic supralinear strokes were also removed. Their analysis shows that Ocropy is able to deal with the complexity of the 'original' text version. Following this line of reasoning, we decided not to reduce the complexity of the training pages except for removing the philological apparatus and footnotes at the bottom of the page and line numbering. Other elements that are part of the Coptic main text block, however, have not been altered or deleted, e.g. brackets, underdots, punctuation, signs signalling page, column and line breaks in the Coptic manuscript as well as superscript footnote signs and other editorial additions to the original Coptic text of the manuscript(s). Therefore, the training set as well as the test set were quite complex.

\subsection{Pre-Processing}

In the preprocessing of the images, ScanTailor [1] was used for cutting pages (2-on-1) and selecting the Coptic text (thus deleting footnotes/critical apparatus and page/line numbers). Particularly helpful but also time-consuming is the despeckling function that makes it possible to delete blobs. The result of despeckling is a very clean b/w image file, but we didn't test systematically if putting a lot of effort into despeckling increases the accuracy to a degree justifying so much manual preprocessing.

\subsection{Ground Truth}

Transcription of the training data was done by the Egyptologist/Coptologist of the team. After an appropriate pause, the transcription was proofread and corrected by the same person. The transcription contains no changes to the text as represented in the edition, i.e. no standardization but also no de-standardization, additions, or corrections. The aim was to represent the text as it is printed in the edition, not to "improve" or "adjust" it as one would do for other purposes.

\subsection{Training}

Springmann [31] recommends 30,000 training steps. We trained for up to 120,000 training steps depending on the tendency that the evaluation of the models showed in intermediate evaluations. As a consequence, models for CSSC_1 were trained for 120,000 steps, for CSSC_2 for 70,000 steps and for CSSC_3 for 95,000 steps. The latter didn't show any promising tendency at that point so that the training process was ended.

\subsection{Evaluation}

Test pages were selected from the data set before training, i.e. were not part of the training data and therefore "unseen" by the OCR engine before evaluation. With respect to the complexity and variation of the character sets, the same criteria as for the data set were used. Both training and test pages were selected in one step without deciding at that point which page would be a part of the training set and which would be used as a test page for evaluation. In doing so we hoped to prevent a bias towards choosing "easy" pages as test pages.

\section{Results}

The accuracy of the prediction varied according to font and reached $>97.5 \%$ (CSSC_2 and CSSC_3) to >99\% (CSSC_1), see Fig. $3 .^{7}$ These numbers are promising especially when considering the complexity and variation of the data and the fact that there was not a post-correction tool involved.

\footnotetext{
${ }^{7}$ CSSC_1 even reached an accuracy of $99,16 \%$ after 115,000 training steps. For lack of space, this is not depicted in the graph in Fig. 3.
} 
The model sets depicted in Fig. 3 are called CSSC_1_20180730, CSSC_2_20180808 and CSSC_3_2018_09_04, respectively. $^{8}$

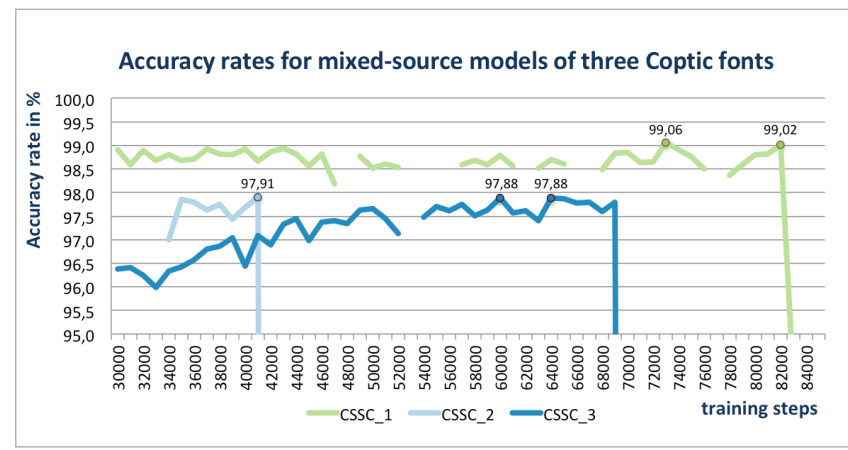

Figure 3: Character accuracy rates for Coptic multi-source data sets $^{9}$

With these rates of accuracy prediction, it can be claimed that OCR will be a helpful tool for researchers who need Coptic texts in digital form, e.g. for further Natural Language Processing purposes. Furthermore, it could be demonstrated that Ocropy is suitable for data sets with a higher degree of variation and complexity.

\section{ACKNOWLEDGMENTS}

The authors would like to thank Heike Behlmer, Camilla Di Biase-Dyson, Frank Feder, Jürgen Knauth, So Miyagawa, Caroline Sporleder, Malte Rosenau and Jörg Wettlaufer for encouragement, hosting the project, their input in discussions and/or technical support.

\section{REFERENCES}

[1] Joseph Artsimovich and Nate Craun. 2007-2014. ScanTailor, version 0.9.11.1. (2014). Accessed on May 18, 2018. http://scantailor.org/.

[2] Guiseppe Balestri and Henry Hyvernat. 1924. Acta Martyrum, Vol. II. Corpus Scriptorum Christianorum Orientalium, Vol. 86. Scriptores Coptici, Vol. 6. Paris, E Typographeo Reipublicae.

[3] Thomas Breuel, Konstantin Baierer, Philipp Zumstein et al. 2017. ocropy. (2017). Retrieved May 18, 2018. https://github.com/tmbdev/ocropy.

[4] Kirill Bulert, So Miyagawa and Marco Büchler. 2017. Optical Character Recognition with a Neural Network Model for Printed Coptic Texts. Digial Humanties 2017, August 08-11, 2017, Montreal, Canada. Retrieved from: https://dh2017.adho.org/abstracts/502/502.pdf.

[5] Paola Buzi. Text structure and readability. In Alessandro Bausi et al. (eds.) 2015. Comparative Oriental Manuscript Studies. An Introduction. Tredition, Hamburg, 147-150. DOI: 10.5281/zenodo.46784.

[6] Pierre Cherix. 2018. Coptica. http://www.coptica.ch.

[7] Leo Depuydt. 1991. Homiletica from the Pierpont Morgan Library. Seven Coptic Homilies Attributed to Basil the Great, John Chrysostom, and Euodius of Rome. Corpus Scriptorum Christianorum Orientalium, Vol. 524. Scriptores Coptici, Vol. 43. Louvain, Peeters.

[8] Leo Depuydt. 1993. Encomiastica from the Pierpont Morgan Library. Five Coptic Homilies Attributed to Anastasius of Euchaita, Epiphanius of Salamis, Isaac of

\footnotetext{
${ }^{8}$ These model sets as well as other (less performing) model sets and the sets of training data will be made available to the scholarly public ([24], login required).

${ }^{9}$ Accuracy rates of the best models are indicated in the graphs. Gaps in the graphs indicate error rates of $>5 \%$ or that the respective training step was not checked against the test pages because an excellent accuracy rate was excluded by the trend of the accuracy/error rate.
}

Antinoe, Severian of Gabala, and Theopempus of Antioch. Corpus Scriptorum Christianorum Orientalium, Vol. 544. Scriptores Coptici, Vol. 47. Louvain, Peeters.

[9] James Drescher. 1970. The Coptic (Sahidic) Version of Kingdoms I, II (Samuel I, II). Corpus Scriptorum Christianorum Orientalium, Vol. 313. Scriptores Coptici, Vol. 35. Louvain, Secrétariat du CorpusSCO.

[10] Gérard Garitte. 1949. S. Antonii Vitae Versio Sahidica. Corpus Scriptorum Christianorum Orientalium, Vol. 117. Scriptores Coptici, Vol. 13. E Typographeo Reipublicae.

[11] Jost Gippert. 2015. Digital approaches to oriental manuscript studies. In Alessandro Bausi et al. (eds.), Comparative Oriental Manuscript Studies. An Introduction. Tredition, Hamburg, 12-27. DOI: 10.5281/zenodo.46784.

[12] The Internet Archive. 2018. https://archive.org

[13] David W. Johnson. 1980. A Panegyric on Macarius Bishop of Tkôw Attributed to Dioscorus of Alexandria. Corpus Scriptorum Christianorum Orientalium, Vol. 415. Scriptores Coptici, Vol. 41. Louvain, Secrétariat du CorpusSCO.

[14] Rodolphe Kasser. 1958. Papyrus Bodmer III. Evangile de Jean et Genèse I-IV,2 en bohaïrique. Corpus Scriptorum Christianorum Orientalium, Vol. 177. Scriptores Coptici, Vol. 25. Louvain, Secrétariat du CorpusSCO.

[15] Rodolphe Kasser. 1960. Papyrus Bodmer VI. Livre des Proverbes. Corpus Scriptorum Christianorum Orientalium, Vol. 194. Scriptores Coptici, Vol. 27. Louvain, Secrétariat du CorpusSCO.

[16] Karl Heinz Kuhn. 1956. Letters and Sermons of Besa. Corpus Scriptorum Christianorum Orientalium, Vol. 157. Scriptores Coptici, Vol. 21. Louvain, Imprimerie Orientaliste.

[17] Karl Heinz Kuhn. 1960. Pseudo-Shenoute on Christian Behaviour. Corpus Scriptorum Christianorum Orientalium, Vol. 206. Scriptores Coptici, Vol. 29. Louvain, Secrétariat du CorpusSCO.

[18] Karl Heinz Kuhn. 1966. A Panegyric on fohn the Baptist. Corpus Scriptorum Christianorum Orientalium, Vol. 268. Scriptores Coptici, Vol. 33. Louvain, Secrétariat du CorpusSCO.

[19] Louis Théophile Lefort. 1925. S. Pachomii Vita Bohairice Scripta. Corpus Scriptorum Christianorum Orientalium, Vol. 89. Scriptores Coptici, Vol. 7. Paris, E Typographeo Reipublicae.

[20] Louis Théophile Lefort. 1933. S. Pachomi Vitae Sahidice Scriptae. Corpus Scriptorum Christianorum Orientalium, Vol. 99. Scriptores Coptici, Vol. 9. E Typographeo Reipublicae.

[21] Louis Théophile Lefort. 1955. S. Athanase Lettres Festales et Pastorales en Copte. Corpus Scriptorum Christianorum Orientalium, Vol. 150. Scriptores Coptici, Vol. 19. Louvain, Imprimerie Orientaliste.

[22] Louis Théophile Lefort. 1956. Euvres des S. Pachôme et de ses disciples. Corpus Scriptorum Christianorum Orientalium, Vol. 159. Scriptores Coptici, Vol. 23. Louvain, Imprimerie Orientaliste.

[23] Johannes Leipoldt and Walter E. Crum. 1913. Sinuthii Archimandritae Vita et Opera Omnia, Vol. IV. Corpus Scriptorum Christianorum Orientalium, Vol. 73. Scriptores Coptici, Vol. 5. Paris, E Typographeo Reipublicae.

[24] Eliese-Sophia Lincke. Coptic OCR, Göttingen Centre for Digital Humanities, Georg-August-Universität Göttingen, Data Sets: PID: 21.11101/0000-0007C9D1-A, https://doi.org/21.11101/0000-0007-C9D1-A.

[25] Eliese-Sophia Lincke. 2016. Optical Character Recognition (OCR) for Coptic. Testing Automated Digitization of Texts with OCRopy. $11^{\text {th }}$ International Congress of Coptic Studies, August 25-30, 2016, Claremont, CA.

[26] Moheb S. Mekhaiel. 2013. Optical Character Recognition for Coptic (OCR). (February 19, 2013). Accessed on January 19, 2019. http://www.moheb.de/ocr.html.

[27] So Miyagawa, Kirill Bulert and Marco Büchler. 2017. Utilization of Common OCR Tools for Typeset Coptic Texts. Extended Abstract. DATeCH 2017, June 01-02, 2017, Georg-August-Universität Göttingen. Retrieved from http://www.academia.edu/33464206/Utilization_of_Common_OCR_Tools_for_ Typeset_Coptic_Texts.

[28] The Oriental Institute. The University of Chicago. 2018. https://oiidb.uchicago.edu.

[29] Tito Orlandi. 1974. Constantini Episcopi Urbis Siout Encomia in Athanasium Duo. Corpus Scriptorum Christianorum Orientalium, Vol. 349. Scriptores Coptici, Vol. 37. Louvain, Scrétariat du CorpusSCO.

[30] Caroline T. Schroeder and Amir Zeldes. 2013-2018. Coptic Scriptorium. Accessed on January 19, 2019. http://copticscriptorium.org.

[31] Uwe Springmann. 2015. Ocrocis. A high accuracy OCR method to convert early printings into digital text. A Tutorial. Center for Information and Language Processing (CIS), Ludwig-Maximilians-Universität München. Retrieved from: http://cistern.cis.lmu.de/ocrocis/tutorial.pdf. 
[32] Uwe Springmann and Anke Lüdeling. 2017. OCR of historical printings with an application to building diachronic corpora: A case study using the RIDGES herbal corpus. Digital Humanities Quarterly 11,2, Article 2. Retrieved from: http://www.digitalhumanities.org/dhq/vol/11/2/000288/000288.html.

[33] Alin Suciu. 2018. Patristics, Apocrypha, Coptic Literature and Manuscripts (Blog). Accessed on August 02, 2018. https://suciualin.files.wordpress.com/. 